\title{
IS COMMUNICATION REALLY FOOD?
}

\author{
Sandra Veinberg \\ Riga International School of Economics and Business Administra- \\ tion (RISEBA), Faculty of Public Relations and \\ Advertising Management, Riga
}

\begin{abstract}
This paper examines a new doctrine for communication. It argues that effective communications are as important to our well being and happiness as the food we put into our bodies. 'It can either be healthy (and nourishing) or toxic (and destructive), notes the Zen master and Buddhist monk, Thich Nhat Hanh. To examine this theory I decided to test my students. Use was made of a non-proportional stratified sample of younger adults, a total of 200 students who were involved in the survey study. Research is also based on an analysis of a qualitative research programme (a qualitative study) which involved 200 questionnaire texts that were set using two methods: critical discourse analysis and context. The results of my research show that students stressed that they were not using traditional forms of media, that the younger reader wants dialogue with the author or journalist, and that they tend to favour relationship-based communications which are offered by social media. My conclusions show that social media is regarded as 'an anti-loneliness tool', and that it encourages a dialogue between the transmitter and the reader and allows a dialogue between them both. Language acts here as a relationship-building resource and shows a level of interaction between text and participants. This shows that, via social media, the internet provides a special form of communication which compensates the audience as might a gourmet restaurant.
\end{abstract}

Key words: Media effects, Communication, Toxic Communication, Social Media, Bakhtin, Thich Nhat Hanh 


\section{Introduction}

Communication history has always been a story of the mass media in the horizontal or vertical frame in order to 'examine the role of communication in the development of the human species and its forms of civilisation'(Willard D. Rowland, 207, p xi). The pioneering work that has been carried out in that direction was started by Walter Ong, Elizabeth Eisenstein, and Harold Innis, and it shares a keen interest in the deep civilisation-related context of all principal forms of communication technologies, thereby encouraging a much richer understanding of the present, rapidly changing experience' (Willard D. Rowland, 207, p xi). But the story of communication is much more central to human history than has been recognised by the formal academic discipline of history itself. Globalisation has introduced adjustments to academic communication research. 'The internet has changed the way [in which] we work, what we consume, how we play, with whom we interact, how we find things out, and myriad other details about the way [in which] we live' (Poe, 2011, p 2). If we turn away from the transmitted and linear method of communication (Friske, 1998; Gruning), from the traditional social, psychological effects of media (McQuail, 1983), from 'the Mentalists' of Walter Ong (Ong, 1958), Eric Havelock (Havelock, 1963) and Jack Goody (Goody, 1977), and the 'Critical Theorists' of Theodor Adorno and Max Horkheimer (Horkheimer, Adorno, 1947), Herbert Marcuse (Marcuse, 1964), from 'Postmodernists' and 'Post-structuralists' (Poster, M. 1990), and the Modern Critical Theory of media studies of Jürgen Habermas (Habermas, 1962) and Noam Chomsky (Chomsky, 1988), and instead place the recipients, the users, at the centre so that in such a situation we can discover that 'meanings are in people, not in words, objects, or things' (Kreps, 1990:29). We can go a step further in the same direction. Therefore, in addition to the Western-centric character of our interpretation of the communication experience, we can begin to study new discoveries in communication research, those that are originating in the East. One of these offers us the investigator of communication and Buddhist monk, Thich Nhat Hanh, with his book, 'The Art of Communicating', 2013. He concentrates on the audience and its relation to the communications process.

Researchers are interested in the audience, and the attitudes and behaviour of users have been considerable since the 1930s. In the past, recipients of the mass communication process were considered as a uniform, homogeneous, passive group of people. Today, the discussion amongst researchers is often about 'active users' and not on 'passive consumers of information'. However, it is clear that the key is the connection for communication or the 'coherence' of the general public, where levels are usually assumed to be equal (Andersson, 1985:93). The context shapes our Western European interpersonal communication process in which the code was 
the key to concept (Falkheimer, 2001, Dimbleby \& Burton, 1994). As 'social animals, human beings depend upon different codes. So far all communication could be broken down into character, as systems form different codes. Signs are usually used to create community, using the very same codes that we use to create symbolic power. A good communicator (a journalist, a source of information, or teachers) has the ability to handle different codes by means of conventions, but the character and meaning of the codes is not natural, but rather culturally determined. At the bottom of all this lies cultural and social mores (Dahlgren, 1994). Feedback is the main signal that shows that the responses of multiple recipients may be different when receiving the very same signal. The new digital information technology explosion provides us with the opportunity for interaction between sender and receiver and shows that the mathematical models of communication (Severin \& Tankard, 1992; Shannon \& Weavers, 1941) are transmissive and unidirectional. Today it is clear that communication may not only be considered as being a two-way process (McQuail \& Winddahl, 1993), which means not only the process employed by socialisation (Gerber, 1994) and this cannot be explained simply by 'the cultural' or 'process school' methods (Curran, 1990). We need new explanations of communication.

The so-called 'Eastern School' of communication research in recent years reveals their ambitions and has offered communication research on the sociolinguistic level (Коган, 1992, 1996), in which the most important instruments in research are the philosophical criteria (Клюканов, 2010). One of the leading researchers in this area is Igor Kljukanov. He uses in his practice of studying communication 'experience + space + time' as a complex measuring instrument (Клюканов, 2010: 59). Interestingly, the direction here is the so-called 'apprehension' theory (McCroskey, J. 2006; Holbrook, H. 1987), which is highly synchronised with the 'Buddhist doctrine of communication'. It argues that effective communications are as important to our well being and happiness as the food we put into our bodies. 'It can either be healthy (and nourishing) or toxic (and destructive)' notes the Zen master and Buddhist monk, Thich Nhat Hanh, in his book on communications. So far, communication has always been regarded as an intellectual process. Thich Nhat Hanh argues that communication is an intellectual process with physiological effect as a result.

\section{Background to the study}

The comparison between information and food is a new way of exploring communications. The entirety of mass communications research is based on the premise that the various forms of media have an influence in any way at all. So far there is no unity amongst researchers as to what should be the ideal communication and 'there 


\section{S. Veinber}

is at least safety and consistency in the preferred effect of communication' (McQuail, 1983:166). Moreover, we 'do not exactly know how a certain effect has occurred or could occur' (McQuail, 1993: 166). Western scientists have conducted research 'on persuasion' (Hovland, 1949; Lazarsfeld, 1944), about 'social effects' (Lang \& Lang, 1959, Halloran, 1965) or 'potential effects' (Carrey, 1987). The attitude of Zen master Thich Nhat Hanh towards communication is very different. He believes that the communication effect can only be either good or bad for the receiver's health. Creating a comparison Creating a comparison between the effects of communication and the effects of gastronomy is a new way of understanding the processes of communication. 'Nothing can survive without food' (Thich Nhat Hanh, 2013: 3). Everything we consume acts either to heal us or to poison us. We tend to think of nourishment only as what we take in through our mouths, but what we consume with our eyes, our noses, our tongues, and our bodies can also be termed food. Thich Nhat Hanh thinks that all of the conversation that goes on around us is also food. It means that we consume and create food when we sit in front of the tv or a computer, or when we listen to a concert. The most important thing is to understand whether or not this communication is healthy for us. How can we tell what communication is healthy and what is toxic? Thich Nhat Han believes that 'the energy of mindfulness is a necessary ingredient in healthy communication' (Thich Nhat Han, 2013, p 5). If you listen to toxic conversation, you must consume those toxins into your body and, thanks to this, you may become angry, frustrated, or sad. You absorb the thoughts, speech, and actions that are going on around you and feel good or bad as a result of this. You produce thoughts, speech, or actions around you and force other people to feel good or bad because of this. So far I have not read any research that analyses the recipient's well-being after the communication process with other people, media, or art. Therefore I chose Thich Nhat Hanh's theory to explore the effect of communicating in the same way as people seek an outcome in the consumption of food. By this I understand that the effects of communication can only be of two types - favourable or unfavourable to human health. 'Every human and every animal communicates. We typically think of communication as the words we use when we speak or write, but our body language, our facial expressions, our tone of voice, our physical actions, and even our thoughts are ways of communicating', points out Thich Nhat Hanh. He believes that 'our communication is not neutral. Every time we communicate, we either produce more compassion, love, and harmony or we produce more suffering and violence' (Thich Nhat Hanh, 2013:139). According him our communication is our karma. The Sanskrit word 'karma' means 'action', and refers not just to bodily action, but to what we express with our bodies, our words, and our thoughts and intentions. 'You are your action - everything we say and do bears our signature', he writes (p 141-142), and sees the link between thinking and how we affect the other people, values, and the world. 


\section{Methodology}

In order to evolve an understanding of the monk's theory, I decided to test my students. Use was made of a non-proportional stratified sample of younger adults, a total of 200 students who were involved in the survey study. All of them were issued with questionnaires. The age of the participants was between 20-33. The validity of the content was high. The survey was carried out between 25/04/2015-25/05/2015. No internal failure was observed. My research is also based on an analysis of qualitative research (in the form of a qualitative study) of 200 questionnaire texts by two methods: critical discourse analysis and context. There are four categories in this analytical model: 1) content, 2) relationships, 3) form, and 4) intertextuality. The method is qualitative and is based on the text and context (Larsson, 2010; Fairclough, 1995; Hellspong, 1997). The content consists of a theme and what the text says (the proposition). A relationship is all about relationship-building with the resources of language such as, for example, a text which contains questions or feelings (exclamation, values, etc), and which encourages dialogue (Larsson, 2010, p 159). The form usually transforms content to a specific, linguistic textual construction. Intertextuality is about the interplay and interaction between text and reader. Intertextuality sees when phrases, words, and whole portions of text are repeated from other texts, calls, and genres, as well as ideas in the text that are similar to those which were formulated earlier (Bakhtin, 1997). Intertextuality includes different test markers (Holqvist, 1997) and the fact that there is a dialogical subject in all expression. I also used Bakhtin's theory and methods: a piece of text is not solitary, rather it is a link in a chain of past and future pieces of text. Therefore I also observed re-contextualisation, which refers to the dialogical relationships between texts: how words move between contexts, how they are used and reformulated, and later assume new meanings (Tannen, 1989; Fairclough, 1995; Linnel 1998; Ajagán - Lester, 2003). All communication aims to reach someone, to influence, strengthen and improve relationships: it builds up a relationship between writer and reader. Therefore, I seek to understand howlanguage can serve as a relationship-building resource. Another important factor in my research is coherence (Bussman, 1983; De Beaugrande, 1996). That a text is coherentmeans that it is coherent and meaningfulboth onalocal and globallevel.

\section{Analysis, findings and results}

\section{Making use of media}

During the discussions, most students stressed that they were not using traditional forms of media. See Table 1. 
The use of media. 2015. RISEBA, Liepaja university (\%)

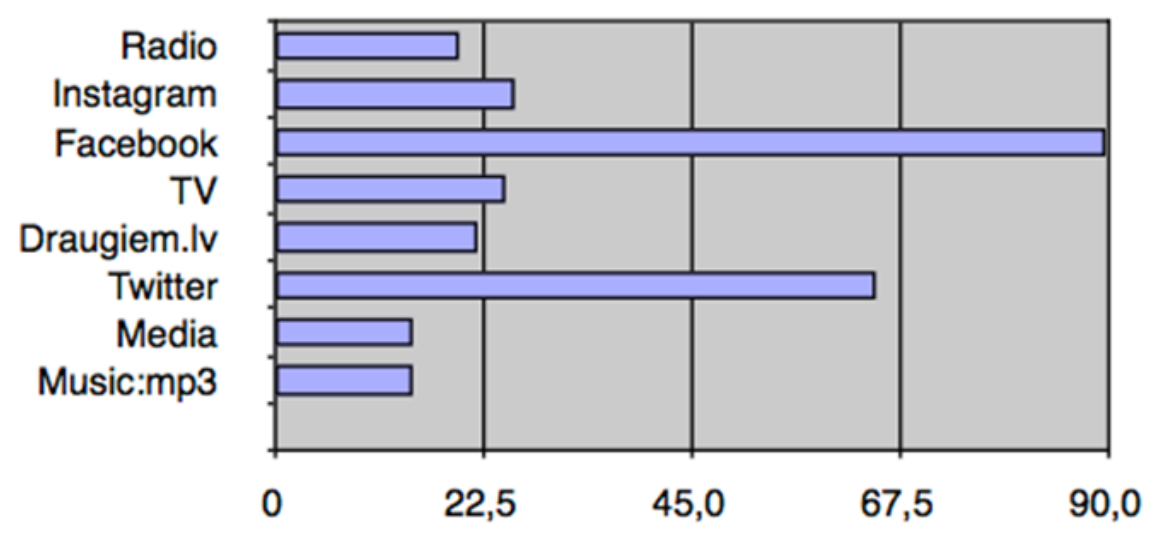

On a daily basis, Facebook and Twitter are the most useful media tools. In third place is Instagram and television. These are followed by the social media resource 'www.draugiem.lv' and the radio. Print media on paper is used in very few situations, and only occasionally. The survey results show that radio has been driven out with the help of the mp3. The content shows a very bleak picture - 'the old media' will no longer work in practice for youths. In reality the contents of these old forms of media usually show up on their computer screens anyway, thanks to Google, Twitter, Facebook or Instagram: 'I do not use print media on paper. I do not listen to the radio, but I often read through social media about the world's events. My favourite is internet radio with good music'; 'I want to know what is going on in the world: about wars, the economy, and things like that.: 'I always need very practical information about the weather, traffic, or culture. This means I search for it on the internet or contact the people who know everything.

The analysis of qualitative research (in the form of a qualitative study) of 200 questionnaire texts shows that the majority of students see a difference in the use of the media when they are at home with their parents, and when they are at university: 'When I'm at home with my parents, I use most of the traditional media such as television. But if I am in Liepaja, I use only the computer and social media', wrote one of students. The use of the media is no longer traditional. 'I daily use many foreign forms of media on the internet', explained one student, a young girl. 'Twitter I usually only read - I never go there to write. I express myself only on Facebook.'

The so-called old forms of media are used most often in the morning: 'I have a ritual - in the morning at breakfast I always watch the tv news. I never look at the 
same channel, but hop between multiple channels in parallel' said one male student.

'Media' for students today are the internet portals www.tvnet.lv, or www. liepajniekiem.lv, which is incredibly popular in Latvia and which has taken over the websites of the biggest newspapers in Riga. This means that the younger reader wants a dialogue with the author or journalist and favours relationship-based communications: 'The content is important, but more important is to know that other people are thinking the same thing, such as 'I do not believe in the media today, it too often writes untruths. Therefore, it's better if we are able to discuss things instead', and 'thanks to social media, I do not feel alone'.

Obviously, the majority of students use daily social media that allows communication feedback. Maybe this shows student desires to be seen and to be heard, the desire to provide feedback (the traditional media only allows one to hear, see, and read). But we cannot exclude the fact that the new forms of media is better able to offer important information.

Relations with forms of mass media have always been a very important factor. The views of today's young people on the media are different, very different than they were during their parents' time. The informal information format is more suited to their needs when it comes to having attractive and more reliable content. Instead of the media they choose blogs, or reports from Facebook, Twitter, or Instagram. They use social networks themselves to appropriate the content from 'old media' and convert this information into an entertaining form that is better addressed for its intended audience.

\section{Which communication is toxic}

Munk's theory of 'healthy' or 'toxic' communication was used in a test on my students (Table 2). Thich Nhat Hanh writes: 'The energy of mindfulness is a necessary ingredient in healthy communication. Mindfulness requires letting go of judgement, returning to an awareness of the breath and the body, and bringing your full attention to what is in you and around you. This helps you to notice whether the thought you just produced is healthy or unhealthy, compassionate or unkind' (Thich Nhat Hanh, 2013, p 5). Unfortunately, the position of the good communication (consuming with mindfulness) was difficult to understand for my students, but 'the toxic conversation' did not lead to the same confusion. 'When you have a conversation with another person, what that person says may be full of toxins, such as hate, anger, and frustration. When you listen to what others say, you're consuming those toxins. You're bringing them into your consciousness and your body' (Thich 
Nhat Hanh, 2013:5). Most of the students knew the text of Thich Nhat Hanh's book and most of them wanted to discuss 'toxic communication' instead of 'good communication'. Because of this, I asked questions only about toxic communication in this regard. The students recognised that they faced on a daily basis the risk that elements of their communication that could be regarded as being unhealthy, and which therefore would fall into the category of 'toxic communication'. Most of them pointed out that, usually, such communication took place between people or in the use of media. 'Yes, every day I meet toxic information in my job and in conversation with friends', concluded one girl and added that 'the same toxic area is in the media. There is constant manipulation'. 'This is an important theme - feeling hatred at work and afterwards feeling bad throughout one's entire body. This is hard', 'I know this from my childhood - there are people who will do anything so that the other person feels worse. They kill my well-being after a normal conversation. This happens!', 'Oh, yes, there are people who disturb my work in any way possible. Especially those who are twice as old as me. I was physically sick later due to this!. 'After each conversation with my employer I can become aggressive and angry, and can feel bad.' 'There are situations in which I as an employer try to explain the details of people who are not sufficiently intelligent. Later on, I feel quite bad [as a result]', 'Poor communication with evil people gives me a headache', 'Do not think that after a conflict, one can find the truth. On the contrary - I feel bad and I feel exhausted'.

The content of all of this displays the following trends: 1) primarily they see themselves only as recipients of information, and 2) they really perceive information that is either appropriate or toxic, just as a small child at the dining table knows what it will and will not eat. Even consumers of communication know what they do not like first and foremost. The results of the survey showed no attempt to dampen their stress levels in regard to other people, although Thich Nhat Hanh in theory accentuates that 'many of us suffer because our communication with other people is difficult. At work, for example, we often feel that we have tried everything and there is no way to reach our colleagues. This is often true in families as well. We feel that our parents, our siblings, or our children are too stuck in their ways. We think that no real communication is possible, writes the author and offers suggestions as to how can we use 'many ways to reconcile and to create openings for more compassionate communication' (Thich Nhat Hanh, 2013:93). Here can we see an active relationship with the themes and the use of strong emotional words such as: 'toxic information', 'toxic area', 'to feel hatred', 'feel bad throughout the entire body', 'this is hard,' 'kill my well-being, 'Oh, yes', 'I feel quite bad'. This means that the recipients 'show their feelings through exclamation marks or watchwords' (Larsson, 2011:159), which are used to demonstrate his attitude by linguistic means. It uses accentuation (Bakhtin, 1981:5), assimilation (Bakhtin, 1981:341), heteroglossia, and a tendency 
to finalise this theme (Bakhtin, 1981: 18).

Here can we explore an active relationship with the themes and with the use of strong emotional words such as: 'toxic information', 'toxic area', 'to feel hatred', 'feel bad throughout one's entire body', 'this is hard', 'kill my well-being', 'Oh, yes', and 'I feel bad'. This means that the recipients 'show their feelings through exclamation marks and watchwords' (Larsson, 2011:159), which are used to demonstrate his attitude through linguistic means. It uses accentuation (Bakhtin, 1981:5), assimilation (Bakhtin, 1981:341), heteroglossia, and a tendency to finalise (Bakhtin, 1981: 18) this theme.

Another girl believed that 'the worst thing is communication between people, but communication with the media is also complicated. 'I hate comments on articles that are found on the internet. Most of them are unnecessarily toxic', said one student, adding that 'the worst thing is that mass communication has already drowned in stupidity and evil'.

Most of the students think this: 'The media publishes too much information without content', 'too much violence,' 'too much misinformation and exaggeration', 'nonsense and cheap entertainment that no one wants to watch', 'boring articles', 'you never have any guarantees that what they write and show is true,' 'all this stupidity in the media must be ignored. The audience's dialogue with these issues was active and powerful: containing intensive expressions, double question and exclamation marks, and drawings that compliment the text.

The survey showed a remarkably high response to and levels of activity for this question. The explanation for this issue was as follows : a) an irritant: 'Because I do not tolerate stupidity and lies', 'does not accept advertising and bad PR'; b) troublesome: 'due to cutting-edge expressions and exaggerations, and coarse language. There are people who think that this attracts attention, but I think that the reality is contrary'; '[an] obsession with [the] sensational'; c) false: 'the media usually build up problems from small matters, and if this happens every day then I feel cheated'. Even here one can observe: 1) feelings through exclamation marks, watchwords, and 2) the same idea system, an internally persuasive discourse (Bakhtin, 1981:327-329), inter-illumination, and minimal heteroglossia (Bakhtin, 1981:18).

A surprise to me was the fact that art can be considered as being an unhealthy form of communication. 'Yes, I often feel that I have been poisoned after going to the cinema or the theatre', one of the students pointed out. Another student thinks that 'long films and concerts can make people feel angry and poisoned' and 


\section{S. Veinber}

others believe that 'the concert or film usually does not correspond to my expectations' or 'takes too much of my energy'. 'Sometimes films force me into an unhealthy psychological situation in which I feel really bad and cannot find a way out', 'there are films and paintings that touch me deeply, but I do not know if this is good or bad'. One of the students emphasised, when he himself was studying modern art in order to understand why the art made him angry and disappointed, 'I think the reason is the unfair conditions in the art industry. Prestige and ideals are just a game for a select group of artists. I know that without having the right contacts it is not possible to be successful [in the art world]. This is the most important tool for reaching the top, but it's one that I do not have. Even in this position students use expressive words and minimal heteroglossia. See Table 2.

\section{Toxic conversation (\%)}

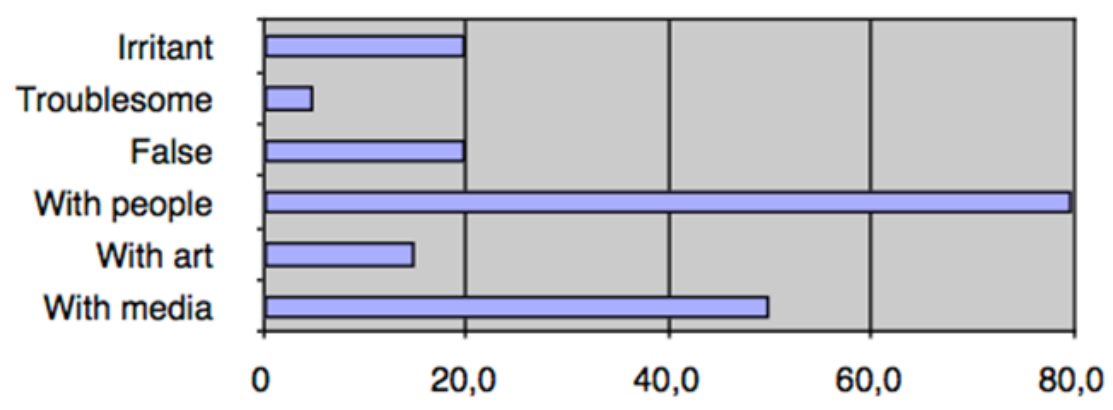

We are lonely together

Thich Nhat Hanh believes that 'we are lonely together' and that 'there's a vacuum inside us' (Thich Nhat Hanh, 2013, p13). To determine whether this applies to us, I asked the students whether this was true (see Table 3). The results showed that social media is 'a tool against loneliness' - as was stated in the results of a survey. If communication is such a sensitive area, how do my students evaluate their participation in social media? I suspected that social media reduces their feeling of loneliness in the media world, but the impact of social media turned out to be wider than this. Toxic communication here is less common. The main reason for participation is that you have the opportunity to teach yourself something new. Every third student believed that social media can be used to learn something new. See Table 3. 


Angry $\bigcirc$ Fun $\bigcirc$ Educational $\bigcirc$ Retweet $\bigcirc$ Chat $\bigcirc$ Observance

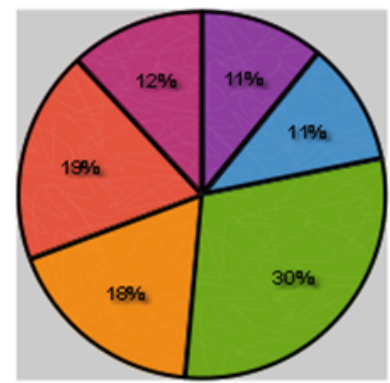

For a total of $19 \%$ of the students, chatting was seen as being a healthy activity, and retweeting was perceived as being a valuable and healthy opportunity to distribute information (18\%). Only 12\% remained angry after communicating through social media and $11 \%$ preferred observation without engaging in communication. A total of $11 \%$ thought that communication should be fun.

'I like to quote wise thoughts', noted one student and most recognise that they quoted wise thoughts more than ten times a month. 'The most difficult thing is to find the truth and to convey it', noted some students. The popularity of the first position 'education' my students explain in this way: 'in school it must be compulsory to teach people to debate and discuss. I have learned this thanks social media', 'I like to follow the wise people on the internet and read what they write right now', 'there are a great many sources of good information', 'Twitter know everything in advance'.

I actually expected more criticism about the discourse on the internet, about the generally low level of the chat on the internet. But criticism was limited. Instead I read: 'it is wonderful to find a good idea and then to be able to give it to friends', 'Sometimes I catch my own thoughts with the additional thought that it would be wonderful if I could discuss the same subject with my peers at work', 'I would like to be able to have such a brainstorm without computers'. Some people do not like the anonymity of the computerised world and point out that: 'the most important thing in life is to meet and talk to people face-to-face. Just so that you can understand other people'. 
Most say that it is wonderful to be able to apply directly to a particular person and 'find answers to their questions directly'. In this position we can observe the following effects: 1) the content here is no longer in unison, 2) the value-criticism is more moderate, 3) form without regularity, and 4) according Bakhtin, we can see here his most famous borrowing from musical terminology - 'the polyphonic' story with 'the maximum complete register of all social voices from the era' (Bakhtin, 1981, p431). According to Thich Nhat Hanh, we can see here how students assess the food that they like in the gourmet restaurant of communication.

\section{Intertextuality and dialogue between the texts}

Table 4.

\section{Intertextual figures (\%)}

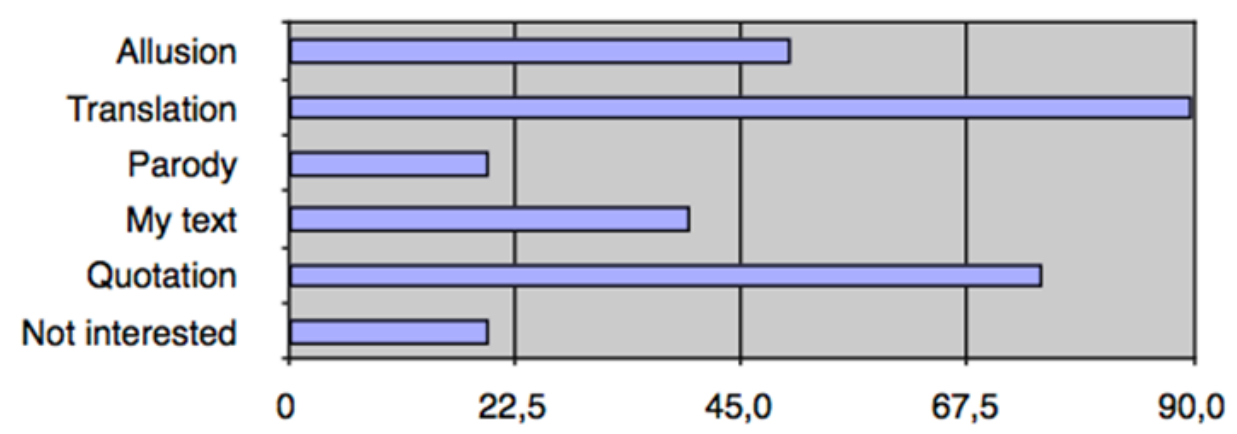

Here I use the popular theory of intertextuality. This resource originates with the dialogue theory by Mikhail Bakhtin that each textual content is in a dialogue with other texts. Intertextuality is no objective truth, but is the projection of the observer's consciousness. Only $45 \%$ of the students thought that they were autonomous in their thoughts, but most recognised their dependence on other people's writings and ideas. The majority of students have chosen the positions 'translation' and 'quotation'. Most of the students state that they do so only for its own sake, and do not retweet or send material on to friends and family. This means that information from social media accumulates and serves as educational material: 'Twitter is my idea bank', 'the most important elements are short, wise thoughts that are not to be found in books, and 'here I have the feedback and hence am a participant in the process. I am reading, thinking and then discussing the issue with people from all corners of the world. In this way I arrive close to the truth, 'if the idea is so good that I like it then I consciously and immediately seek out more information about the author and his other ideas and expanded my knowledge'. 
Allusion is in third place and is used mostly for fun, often in the form of puns: 'sometimes I do retweet it for me, for the good memories, or simply because it is fun. Simply fun', 'allusion raises other areas of curiosity', 'if it coincides with my views then this can be used.

It's in terms of Bakhtin's 'already bespoke quality' (Bakhtin, 1981: 8 -9), and 'simultaneous appropriation and transmission' (Bakhtin, 1981:341).

A 'quotation' is something that many also consider a tool: 'I use this on my birthday. Then I send sensible quotes to friends and family'. Many note that this is something that is very unique: 'I like to quote only something that is very, very important, something that makes sense and has essence.' Many admit that the quote is characterised notby its punctuation, but with the help of a particular expression in the text. However, a large number of students belong to the traditional school: 'first you use quotes, then you refer to the authors and 'use them only if [what they say] is useful and content-rich. Again this already contains bespoke quality' (Bakhtin, 1981: 8-9).

Only in the four places is 'my text', showing that students understand the effects of intertextuality and recognise that their thoughts are influenced by other people's thoughts.

Intertextuality can be viewed from different perspectives: 1) ideological, 2) semiotic, and 3) being from a communicative perspective. I understand the intertextuality' in the form of it being a tool which helps us to study the textual system, which itself flows into the other texts. The best way to prove it is in the study of dialogues between the texts.

Most of the students recognised that: 1) they adopted alien texts unconsciously: 'it is clear that this happens unintentionally! Yes, I use symbols that I have borrowed from other people, 'it can be the case that, unwittingly, grains of an idea remains in the memory. Information is updated in my head if it is important to me'. 'It may also be the case that I unconsciously tend to incorporate these strangers ideas in my own works. At that moment I feel these ideas are my own. As such, that's coming from me', 'it is conceivable that, both in speech and writing, I use borrowed thoughts and ideas. I'll think about it now in my art', 'there are situations in which something happens accidentally'; 'one thought leads to the next and then to other thoughts. Then we can no longer distinguish between the beginning of my idea and the end of another person's idea'. Some acknowledge that it may be the case that alien ideas and texts are used deliberately ' his works are incredible knowing' or 'the space of information today is common to all. Therefore it is impossible not to be swayed 


\section{S. Veinber}

by others'; 2) that a stranger's text is a good form of text if it confirms their own thoughts : 'if the text is concise and witty', 'if an idea is close to me and coincides with my vision of the world', 'as a young artist I was looking for ideas everywhere. They are both articles and images, both video and films. You can almost always find good things and pick them up yourself, but by this I don't mean copying; and, finally 3) it's okay if it is possible to compare ideas and thoughts: 'the ideas of others can affect me just as much as I myself want to be affected', 'yes, of course its true that only through communication can one reach the result and create new views which I can then generate and reflect upon', 'it is important to be able to compare foreign ideas with one's own'. According Bakhtin, this tendency can be a dialogue with 'alien text and can be noted also in 'reaccentuation' (Bakhtin, 1981:5).

Cutting-edge ideas forms another important item: 'in this way I look for inspiration for my work', 'if the ideas are dazzling and cutting-edge then I try to seize them directly', 'I certainly do catch them, because in this kind of idea is inspiration for my work', 'ideas in social media are so diverse and often unexpected that I am often shaken by them. It's great to know that such a platform exists, and that I can use those thoughts that attract my attention'.

Table 5.

Dialogue between the texts (\%)

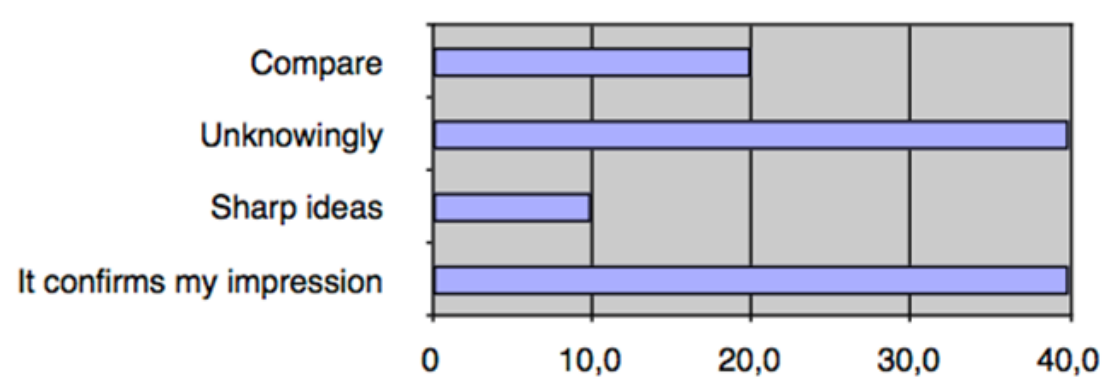

The term 'cutting-edge ideas' or 'sharp ideas' does not only have to be a source of inspiration. By this term students also understand: 'particularly important notices such as asking for help and political declarations', and 'other important human messages'. Such information may be important in different ways: 1) 'to compare', or 2) 'to share with other people'. Generally, when it comes to a description of 'cutting-edge the following words dominate: 'current', 'essential', 'laconic', and 'shocking', which 'often become a source of inspiration'. This shows a fairly large degree of heteroglossia according to Bakhtin. This post shows how dialogism (Bakhtin, 1981, p411) works in practice. 'Dialogism is the characteristic epistemological mode of 
a world that is dominated by heteroglossia' (Holqvist M. and Bakhtin, 1981; 411). Social media promotes dialogue between the transmitter and the reader and allows a dialogue between them. Language acts as a relationship-building resource and shows an interaction between texts and participants. 'When we see other people who are enjoying good levels of communication with themselves and with others, they inspire us... In these cases, the energy of a community of mindfulness can help us to embrace and release suffering that we could not be able to achieve by ourselves' (Thich Nhat Hanh, 2013:131).

\section{Discussion and conclusion}

1) Communication is food. Thich Nhat Hanh's idea is correct. Communicators find, select, and use information in the same way as people choosing food. Everything is determined by taste and experience. It is easy to say that you do not like something because it does not taste that good, but it is almost impossible to present food for all tastes all of the time.

2) Just like going to a gourmet restaurant, young people choose the information they want on the internet: they select only that 'food' that suits their tastes because they want to feel good.

3) The content of the survey shows a very bleak picture when it comes to the old media. They will no longer work in practice for young people. In reality the material generated by old forms of media pops up on their computer screens anyway - thanks to Google, Twitter, Facebook, or Instagram - but the young reader wants to have an dialogue with the author or journalist and favours the relationship-based communications that are being served up by social media.

4) Young people need attractive media that is more open and equal than was previously the case - media such as blogs, or reports from Facebook, Twitter, or Instagram. Social networking can itself appropriate the content from the 'old media' and convert it into an entertaining format that better suits a young audience.

5) Through this study, it can be seen that modern users of social media demonstrate and confirm in practice Bakhtin's theory. This survey proves that communication is a form of dialogue between different texts. This means that the exchange of thoughts in internet communication is an exchange of texts which, essentially, is a multi-consciousness dialogue as indicated by Bakhtin, not the 'mosaic of quotations' that Kristeva claims. 
6) It can be concluded that every text in social media has a feature that provides an echo. Thoughts will be echoed in the form of text. This unique speciality - 'the reverberation of text in internet communications' - should certainly be studied increasingly widely.

\section{References}

Ajagán - Lester, L. (2003). Intertextualiteter: Eds. Ledin, P. \& Englund, B. Teoretiska perspektiv på sakprosa. Lund. Studentlitteratur.

Andersson, L. (1985). Fult språk. Stockholm. Carlssons.

Bakhtin, A. (1981). The Dialogue Imagination. Four Essays by M. M. Bakhtin. The University of Texas Press.

Bakhtin, M. (1997). Frågan om talgenrer. In Götselius, T. (Eds). Genreteori. Lund: Studentlitteratur. Bakhtin, M. (1981). The Dialogic Imagination: Four Essays by M. M. Bakhtin. Ed. Holquist, M. Aus tin. University of Texas Press.

Bussmann, H. (1983). Lexikon der Sprachwissenschaft. Stuttgart, Kröner.

Chomsky, N. (1988). Manufacturing Consent: The Political Economy of the Mass Media. New York, Pantheon Books.

Curran, J. (1990). The New Revisionism in Mass Communication Research: A Reappraisal, s. 135. In European Journal of Communication. Vol.5, 2-3 June.

Dahlgren, P. (1994). Upptäck massmedierna. 2 upplagan. Stockholm. Natur och Kultur.

De Beaugrande, R.\& Dressler, W. (1996). Introduction to text Linguistics. New York: Longman.

Dimbleby, R. \& Burton, G. (1994). More than words - an introduction to communication. 2nd ed., London, Routledge.

Fairclough, N. (1992). Discourse and social change. Cambridge Polity.

Fairclough, N. (1995). Media Discourse. London. Edward Arnold.

Falkheimer, J. (2001). Medier och kommunikation. Studentlitteratur. Lund.

Friske, J. (1998). Kommunikationsteorier - en introduktion, Stockholm, Wahlström \& Widstrand.

Gerber, G. (1994). Growing up with Television: the Cultivation Perspective. In Media Effects - Ad vances in Theory and Research. New Jersey. Lawrence Erlbaum Ass.

Goody, J. (1977). The Domestication of the Savage Mind. Cambridge, Cambridge UP.

Grunig, J. (2013). Excellence in Public Relations and Communication Management. Routledge Communication Series.

Habermas, J. (1962). Strukturwandeln der Öffentlichkeit. Neuwied. H. Luchterhand.

Hanh, T, H. (2013). The Art of Communicating. New York. HarperCollins Publishers.

Havelock, E. A.(1963). Preface to Plato. Cambridge. Harvard.

Hellspong, L. \& Ledin, P. (1997). Vägar genom texten. Lund. Studentlitteratur.

Horkheimer, M \& Adorno, T. (1947). Dialektik der Aufklarung. Amsterdam, Querido Verlag.

Клюканов, И. (2010). Коммуникативный универсум. Москва, Российская политическая энциклопедия.

Holbrook, H. (1987). Communication Apprehension: The Quiet Student in Your Classroom. Clear inghouse on Reading.

Коган, П. (1996). Философия: серьезное и веселое. Москва.

Коган, П. (1992). Социология культуры. Свердловскю

Коган Л. (1992). Социология культуры. - Екатеринбург.

Kreps, G. (1990). Organizational communication: theory and practice. 2nd ed., New York. Longman. Kristeva, J. (1980). Desire in Language: A Semiotic Approach to Literature and Art, Oxford: Blackwell. 
Larsson, L. (2010). Metoder i kommunikationsvetenskap. Lund. Studentlitteratur.

Linnel, P. (1998). Approaching Dialogue: Talk and Interaction in Dialogical Perspectives. Amster dam. John Benjamin's Publishing.

Marcuse, H. (1964). One - Dimensional Man. Boston. Beacon.

McCroskey, J. (2006). An introduction to rhetorical communication: A Western rhetorical perspect ive. Boston, MA: Allyn \& Bacon.

McCroskey, J. C. (2001). An introduction to rhetorical communication. Boston, MA. Allyn \& Bacon.

McQuail, D. (1983). Masskommunikationsteori. Malmö, Liber Förlag.

McQuail, D \& Windahl, S. (1993). Communication Models for the Study of mass Communication. 2nd ed., London, Longman House.

Ong, W. (1958). Method and the Decay of Dialogue. In Art of Discourse to the Art of Reason. Cam bridge, Harvard.

Poe, M. (2011). A History of Communication. New York, Cambridge University Press.

Poster, M. (1990). The Mode of Information: Poststructuralism and Social Contexts. Chicago, Uni versity of Chicago Press.

Severin, W \& Tankard, J. (1992). Communication Theories: Origins, Methods and Uses in the Mass media, 3rd edition, New York, Longman.

Shannon, C \& Weaver, W. (1949). The Mathematical Theory of Communication. Urbana. University of Illinois Press.

Tannen, D. (1989) Talking Voices. Repetition, dialogue and imagery in conversational discourse. Cambridge. Cambridge University Press.

Thich Nhat Hanh. The Art of Communicating. New York. Harper Collins Books.

Willard. D. Rowland. Eds. Crowley, D, Heyer, P (2007). Communication in History. Fifth Edition. Boston. Pearson Education Inc. 